\title{
Anteaters on the edge: giant and lesser anteaters (Myrmecophaga tridactyla and Tamandua tetradactyla) at their geographic distributional limits in Paraguay
}

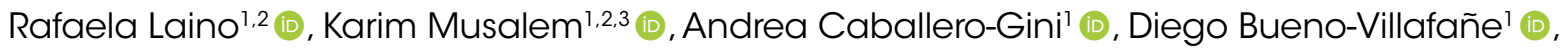 \\ José F. González-Maya ${ }^{4}$ [D, Silvina Chaparro' ${ }^{10}$
}

\author{
1. American Chaco Research Center, San José 365, Asunción, Paraguay. (rafilaino@gmail.com; ancgini@gmail.com; diegobuenov@gmail.com; \\ silvichaparro1080@gmail.com) \\ 2. International Foundation for the Restoration of Ecosystems, 28008 Madrid, Spain. \\ 3. World Wildlife Fund for Nature. Bernardino Caballero 191, Asunción, Paraguay. \\ 4. Proyecto de Conservación de Aguas y Tierras, ProCAT Colombia/International, Carrera 11 \#.96-43, Bogotá, Colombia. (jfgonzalezmaya@gmail.com)
}

Received 23 June 2019

Accepted 7 April 2020

Published 22 May 2020

DOI: 10.1590/1678-4766e2020007

\begin{abstract}
Species tend to be less abundant at the limits of their geographic distribution. Giant and lesser anteaters have their southernmost limits in Argentina and Paraguay, where scarce information exists regarding their ecology and conservation. We present a study carried out in the Paraguay River floodplain, in an area dedicated to cattle rearing using native grasses in a subtropical flooded savanna associated with naturally occurring forest islets, wetlands and palm groves. Using camera-traps within three different forest types, we estimated parameters related to habitat preference, social behavior and activity patterns of both species. Results show that capture success was greater in the Floodable sub-humid forest islets (FSF), compared to other types of forests: Riparian forests associated with wetlands (W-RF) and Mesoxerophytic semi-deciduous forests dominated by Schinopsis balansae (MXF). Most detections corresponded to solitary anteaters, although mother-young pairs were occasionally observed during summer. Both species showed a nocturnal and crepuscular activity pattern with a peak of records around midnight. Myrmecophaga tridactyla was detected between $11^{\circ} \mathrm{C}$ and $26^{\circ} \mathrm{C}$, while Tamandua tetradactyla occurred between $15^{\circ} \mathrm{C}$ and $23^{\circ} \mathrm{C}$. Future research that incorporates systematically taken data in other different habitats, including grasslands and shrublands, during all seasons of the year is recommended.
\end{abstract}

KEYWORDS. Camera-traps, Humid Chaco, floodable forest.

RESUMEN. Osos en el borde: oso hormiguero gigante y oso melero (Myrmecophaga tridactyla y Tamandua tetradactyla) en sus límites de distribución geográfica en Paraguay. Las especies tienden a ser menos abundantes en los límites de su distribución geográfica. El oso hormiguero y el oso melero tienen su límite de distribución al Sur en Argentina y Paraguay, donde existe escasa información sobre su ecología y conservación. Presentamos un estudio realizado en la planicie de inundación del Río Paraguay, en un área dedicada a la ganadería sobre pasturas nativas en sabanas subtropicales inundables asociadas con isletas de bosques naturales, humedales y palmares. Estimamos parámetros referentes a preferencia de hábitat, comportamiento social y patrones de actividad de ambas especies a través del uso de cámaras trampa en tres tipos de bosques. Los resultados indican que el éxito de captura fue mayor en las islas de bosques subhúmedos inundables, comparado con los otros tipos de boques: bosques riparios asociados a humedales y bosques semicaducifolios mesoxerofíticos dominados por Schinopsis balansae. La mayoría de las capturas corresponde a osos solitarios, aunque ocasionalmente fueron observadas hembras cargando a sus crías durante el verano. Ambas especies mostraron un patrón de actividad nocturno y crepuscular con un pico de registros alrededor de la medianoche. Myrmecophaga tridactyla fue detectado entre $11^{\circ} \mathrm{C}$ y $26^{\circ} \mathrm{C}$, mientras que Tamandua tetradactyla apareció entre $15^{\circ} \mathrm{C}$ y $23^{\circ} \mathrm{C}$. Se recomiendan futuras investigaciones que incorporen datos tomados sistemáticamente en otros tipos de hábitats, incluyendo pasturas y matorrales, durante todas las estaciones del año.

PALABRAS CLAVE. Cámaras trampa, Chaco Húmedo, bosque inundable.

The giant anteater (Myrmecophaga tridactyla Linnaeus, 1758) is distributed from Honduras, through Paraguay and Argentina (Miranda et al., 2014a); while the lesser anteater (Tamandua tetradactyla Linnaeus, 1758) occurs only in South America (MirANDA et al., 2014b). Both species occur sympatrically throughout most of their geographic distribution (FonsECA et al., 1996; PAGLIA et al., 2012). However, very little information exists on the population status of the giant anteater across its range
(Quiroga et al., 2016), especially in Paraguay (De LA SANCHA et al., 2017).

Myrmecophaga tridactyla is listed as Vulnerable by national (APM \& SEAM, 2017) and global (IUCN, 2014a) assessments. The species is considered the most threatened mammal of Central America, apparently extirpated from Belize and Guatemala, and has disappeared from parts of Costa Rica (Miranda et al., 2018). In addition, the national status for M. tridactyla in Uruguay is Extinct (FonsECA \& 
Rylands, 2004; FALlabrino \& CASTIÑEIRA, 2006), locally extinct in some parts of Brazil (ChiARello et al., 2007; Miranda et al., 2018) and eastern Paraguay (SMITH, 2012).

The main causes of decline of the giant anteater populations are the reduction, deterioration and fragmentation of habitats (Rodrigues et al., 2008; De Matos et al., 2019). There is considerable uncertainty regarding how fast the species responds to habitat loss, and how time-delayed responses vary in space (SEMPER-PASCUAL et al., 2018). Habitat loss may lead to a decrease in population size and isolation among remnant populations; for instance, Collevatti et al. (2007) showed that the population of $M$. tridactyla in Emas National Park (Brazil) has a low level of genetic diversity and a high level of inbreeding.

Tamandua tetradactyla is listed as Least Concern at national (APM \& SEAM, 2017) and global (IUCN, 2014b) levels. The species is widespread in Paraguay, but local extinction has occurred in large areas of eastern Paraguay, remaining common in the Humid Chaco but less so in the Dry Chaco (Sмiтh, 2007). In Uruguay, T. tetradactyla is considered threatened or insufficiently known (FALLABRINO \& CASTIÑEIRA, 2006).

The distribution of anteaters is poorly known, there is no information regarding the abundance of individuals and there is little data available for wild populations especially outside Brazil (SMith, 2007; Alzate-GaVIRIa et al., 2016; Miranda et al., 2018). Even recently, some unexpected records of $M$. tridactyla outside the range of the known distribution for the species have also been reported (e.g. in an interandean zone of Colombia, Figel et al., 2015).

Habitat preference in giant and lesser anteaters varies among regions. In the Brazilian Pantanal, for instance, $M$. tridactyla was recorded mostly in open grasslands, scrub grasslands and forest edges, while T. tetradactyla was found mainly in forests and forest edges (DESBIEZ \& MEDRI, 2010).

Although giant anteater studies can be found in Brazil (MiretzKi \& Goss Braga, 2014; Passos et al., 2016; Mamalis et al., 2018) and the North of Argentina (Perez Jimeno \& Llarin AMAYA, 2009; QUIROGa et al., 2016), data of these species in Paraguay is still scarce or even absent (DE La Sancha et al., 2017; Smith \& Rios, 2018). Most of the Paraguayan Chaco (a convergence of Pantanal, Cerrado, Dry and Humid Chaco ecoregions) is located within the area of the M. tridactyla geographic distribution, however, our study area is located a few kilometers from the possibly extinct zone towards the southern limit (MIRANDA et al., 2014a).

The aim of this research was to study the giant and the lesser anteaters in the Paraguayan Humid Chaco using camera-traps in order to estimate parameters related with habitat preference, social behavior and activity patterns of both species in this poorly known region of their distribution.

\section{MATERIALS AND METHODS}

Study area. The study was performed in a cattle ranch of the Humid Chaco Ecoregion in Paraguay (Fig. 1). The property is located in the floodplain of the Paraguay River and is mainly dedicated to extensive free-range cattle ranching since at least 1904, however, no evidence of drastic forest clearings was found in the last 114 years (visual comparative of a drawn map from 1904 signed by E. DomingueZ and vegetation map elaborated by Z. EL RAISs), maintaining its original vegetation cover, except for selective extraction of wood used for cattle ranching infrastructure (i.e., cabin construction, fencing and bridges mostly from Schinopsis balansae Engler, Copernicia alba Morong and Prosopis spp.) (LaINo et al., 2017). Predominant ecosystems of the area include wetlands and natural vegetation formations conditioned by topography and frequent flooding (GINZBURG \& ADAMOLI, 2006) creating a mosaic of subtropical forests, grasslands and marshes (Mereles et al., 2013). Rainfall averages $1,200 \mathrm{~mm}$ per year, and the temperature means $15^{\circ} \mathrm{C}$ in the coldest periods (June-August) and $28^{\circ} \mathrm{C}$ in the hottest months (December-February) (Mereles et al., 2013; $\mathrm{DMH}, 2018)$. The total ranch area is 4,000 ha, however the sampling site covered 500 ha non-randomly selected according to accessibility and flooding conditions during the time of the sampling.

The study was conducted in three vegetation types: i) Riparian forests associated to wetlands (W-RF), ii) Mesoxerophytic semi-deciduous forests dominated by Schinopsis balansae (MXF), and iii) Floodable sub-humid forest islets (FSF) (Fig. 1). Wetlands are low floodable areas which vary with the rainy season, where vegetation is represented by emergent stands of Typha, Cyperus and Thalia; in open waters, also including floating stands of Pistia, Eichornia, Victoria among others (PEÑA-CHOCARro et al., 2006). W-RF in our study site are usually associated to a $\sim 50-100 \mathrm{~m}$ riparian forest strip linked to periods of flooding (Maturo et al., 2005; PeÑa-ChOCARro et al., 2006); common tree species for our study site are Peltophorum dubium (Spreng.) Taub., Ocotea diospyrifolia (Meisn.) Mez, Nectandra angustifolia (Schrad.) Nees, Inga vera Willd, and Genipa americana L., with lower presence of Vitex megapotamica (Spreng.) Moldenke and Terminalia trifolia Spreng. MXF or quebrachales are dominated by Schinopsis balansae and Libidibia paraguariensis (D. Parodi) Burkart and occasionally Aspidosperma quebracho-blanco Schltdl. (Mereles, 2005; PeÑa-Chocarro et al., 2006). FSF are present in the Paraguay River floodplain and are associated with palm groves of Copernicia alba (PEREZ DE Molas, 2016). Some tree species of the FSF are common with the riparian forest, however, these forests occur in welldefined islets, usually surrounded by savannas rather than following the course of streams or wetlands; some species common to this type of forest and our study site include: Peltophorum dubium, Enterolobium contortisiliquum (Vell.) 


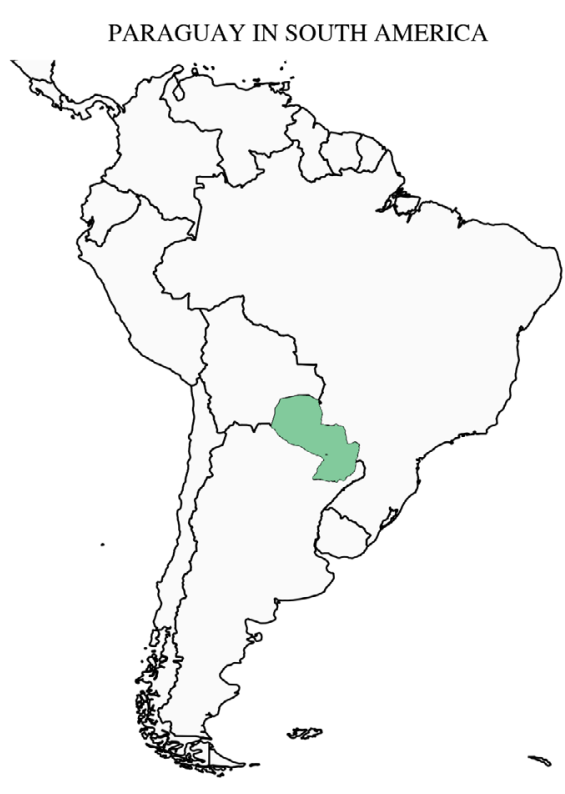

LOCATION IN PARAGUAY

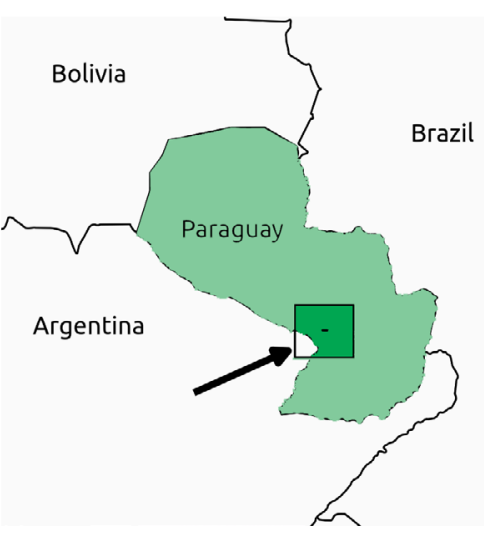

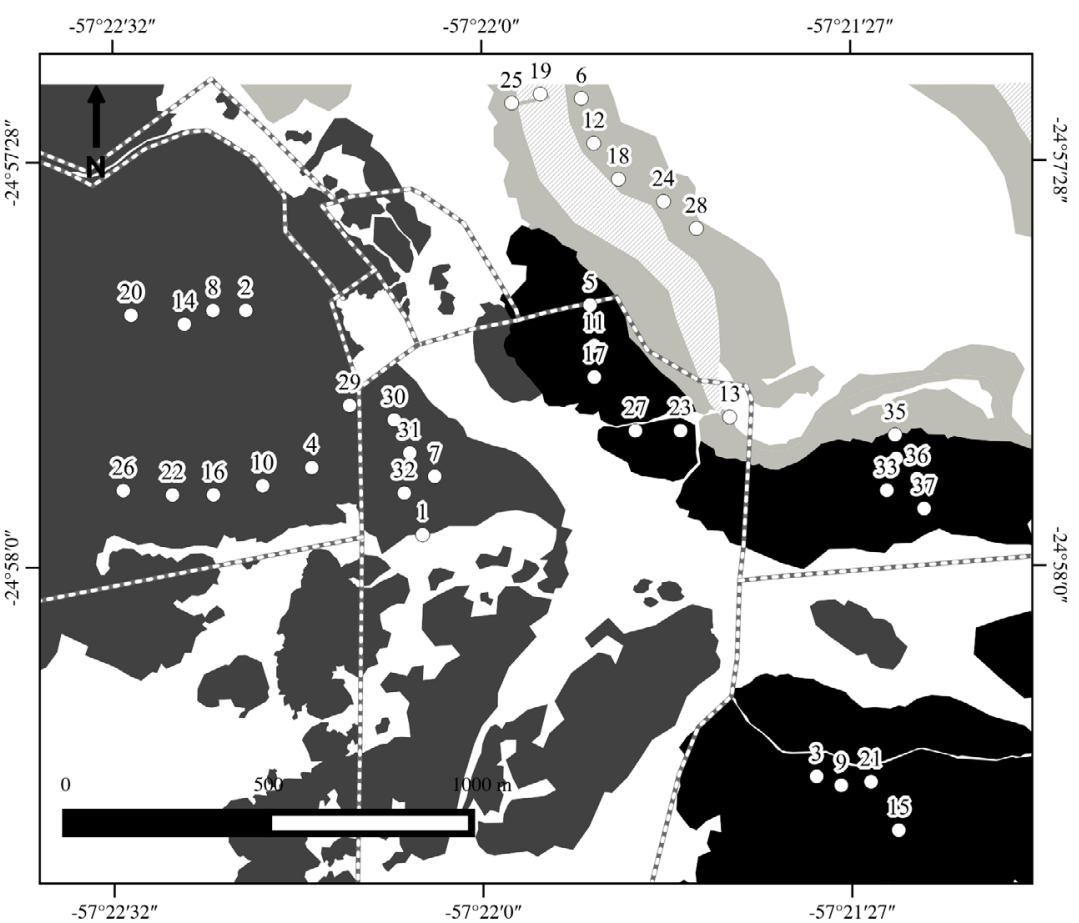

Legend

- Trap camera

$\ldots \times$ Cattle fence

Vegetation types

FSF: Floodable sub-humid forest

MXF: Mesoxerophytic semi-deciduous forest

W-RF: Riparian forest associated with wetlands

Wetland

Flooded savanna

Geographical Projection WGS 84 Made with QGIS

Fig. 1. Location of the study area in the Humid Chaco Ecoregion in Paraguay (left) and camera-trap ubications from November 2016 to March 2018. The numbers of the amplified area (right) indicate the date and season in which the trap cameras were placed in the different forests types (see Tab. I).

Morong, Ficus enormis (Miq.) Miq., Ocotea diospyrifolia, Sapium haematospermum Müll.Arg., Gleditsia amorphoides (Griseb.) Taub., Guazuma ulmifolia Lam., Chloroleucon tenuiflorum (Benth.) Barneby \& J.W.Grimes, Handroanthus heptaphyllus (Vell.) Mattos, Syagrus romanzoffiana (Cham.) Glassman and Copernicia alba.

Methods. We used five Bushnell Trophy Cam HD Essential camera-traps from November 2016 to March 2018. Cameras were installed $45 \mathrm{~cm}$ above the ground and were programmed to operate $24 \mathrm{~h} 00$ per day, reaching a total sampling effort of 1,268 camera-days. Camera-traps were rotated in the three forest types previously described: i) Riparian forests associated to wetlands (W-RF), ii) Mesoxerophytic semi-deciduous forests dominated by
Schinopsis balansae (MXF), and iii) Floodable sub-humid forest islets (FSF) (Tab. I, Fig. 1). Cameras were rotated to standardize sampling efforts across habitat types.

Photographs and videos taken by camera-traps were considered records (see two records of this research in Figs $2,3)$. Only the first record was considered when more than one photograph or video of the same species was taken at the same camera-trap within a $1 \mathrm{hr}$ interval. Between 1 and 21 photos and 0 and 3 videos were obtained for each record for this study. Sampling effort and capture success were calculated according to SrbeK-Araujo \& Garcia Chiarello (2005) (Tab. II). Social behavior was described through the patterns of activity and number of individuals in each record. 
Tab. I. Forest type, camera-trap locations from November 2016 to March 2018 (date and season) and sampling effort (camera-days) for the study of giant anteater (Myrmecophaga tridactyla Linnaeus, 1758) and lesser anteater (Tamandua tetradactyla Linnaeus, 1758) in the Humid Chaco Ecoregion in Paraguay (W-RF, Riparian forests associated to wetlands; MXF, Mesoxerophytic semi-deciduous forests dominated by Schinopsis balansae; FSF, Floodable sub-humid forest islets).

\begin{tabular}{|c|c|c|c|c|}
\hline Forest type & $\begin{array}{l}\text { Camera-trap } \\
\text { locations* }\end{array}$ & $\begin{array}{l}\text { Study period } \\
\text { (dates) }\end{array}$ & $\begin{array}{l}\text { Season of } \\
\text { the year }\end{array}$ & $\begin{array}{c}\text { Sampling effort } \\
\text { (camera-days) }\end{array}$ \\
\hline \multirow{2}{*}{ W-RF } & $13-19-25$ & November 18, 2016 to January 19, 2017 & Spring-summer & 180 \\
\hline & $6-12-18-24-28$ & September 21 to November 7, 2017 & Spring & 235 \\
\hline \multirow{3}{*}{ MXF } & $3-9-15-21$ & April 1 to 30,2017 & Autumn & 120 \\
\hline & $5-11-17-23-27$ & August 18 to Septermber 20, 2017 & Winter & 160 \\
\hline & $33,34,35,36$ y 37 & February 7 to March 7, 2018 & Summer & 140 \\
\hline \multirow{4}{*}{ FSF } & $1-7$ & November 18, 2016 to January 19, 2017 & Spring-summer & 108 \\
\hline & $2-8-14-20$ & March 16 to 31,2017 & Summer-autumn & 60 \\
\hline & $4-10-16-22-26$ & July 18 to August 16,2017 & Winter & 133 \\
\hline & $29,30,31$ y 32 & November 9 to December 12, 2017 & Spring & 132 \\
\hline Total camera-days & & & & 1,268 \\
\hline
\end{tabular}

* See camera-trap geographic locations in Fig. 1.

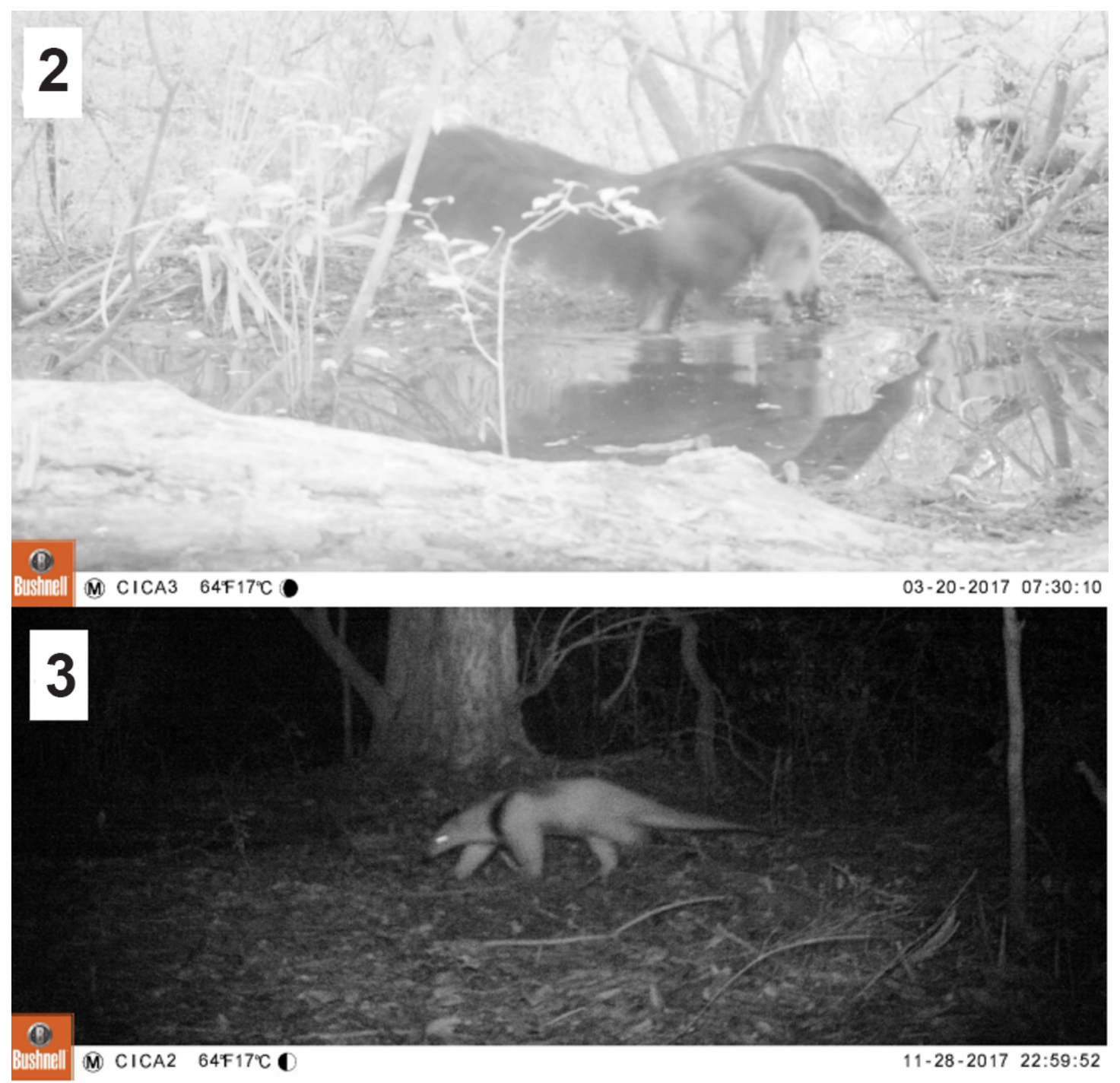

Figs 2, 3. Photos taken by trap cameras in the Humid Chaco Ecoregion in Paraguay: 2) Giant anteater (Myrmecophaga tridactyla Linnaeus, 1758) on March 20th, 2017; 3) Lesser anteater (Tamandua tetradactyla Linnaeus, 1758) on November 28th, 2017. 
Tab. II. Sampling effort (camera-days), number of records and capture success (\%) of giant anteater (Myrmecophaga tridactyla Linnaeus, 1758) and lesser anteater (Tamandua tetradactyla Linnaeus, 1758) by forest type and season of the year in the Humid Chaco Ecoregion in Paraguay using cameratraps from November 2016 to March 2018 (W-RF, Riparian forests associated to wetlands; MXF, Mesoxerophytic semi-deciduous forests dominated by Schinopsis balansae; FSF, Floodable sub-humid forest islets).

\begin{tabular}{|c|c|c|c|c|c|}
\hline & $\begin{array}{c}\text { Sampling effort } \\
\text { (camera-days) }\end{array}$ & $\begin{array}{c}\text { Number of records of } \\
\text { M. tridactyla }\end{array}$ & $\begin{array}{l}\text { Capture success (\%) } \\
\text { of M. tridactyla }\end{array}$ & $\begin{array}{c}\text { Number of records of } \\
\text { T. tetradactyla }\end{array}$ & $\begin{array}{c}\text { Capture success (\%) } \\
\text { of T. tetradactyla }\end{array}$ \\
\hline \multicolumn{6}{|c|}{ By forest type } \\
\hline W-RF & 415 & 5 & 1.20 & 1 & 0.24 \\
\hline MXF & 420 & 2 & 0.48 & 3 & 0.71 \\
\hline FSF & 433 & 10 & 2.31 & 5 & 1.15 \\
\hline \multicolumn{6}{|c|}{ By season } \\
\hline Spring & 513 & 10 & 1.95 & 6 & 1.17 \\
\hline Summer & 302 & 3 & 0.99 & 1 & 0.33 \\
\hline Autumn & 160 & 1 & 0.63 & 1 & 0.63 \\
\hline Winter & 293 & 3 & 1.02 & 1 & 0.34 \\
\hline
\end{tabular}

\section{RESULTS}

Habitat preference. Mean capture success for $T$. tetradactyla was $0.7 \%$ and $1.3 \%$ for M. tridactyla (Fig. 4). In both species, capture success was greater in Floodable sub-humid forest islets (FSF). T. tetradactyla appeared more frequently in FSF (1.2\%), followed by Mesoxerophytic semideciduous forests dominated by Schinopsis balansae (MXF) and Riparian forests associated to wetlands (W-RF), with $0.7 \%$ and $0.2 \%$, respectively. While, $M$. tridactyla capture success was greater in FSF (2.3\%), followed by W-RF (1.2\%) and MXF $(0.5 \%)$.

Social behavior. Most detections consisted of individual anteaters for both species (Figs 2, 3), for $M$. tridactyla, $88 \%(\mathrm{n}=15)$ records were of solitary giant anteaters and $12 \%(n=2)$ were mother-young pairs; juvenile giant anteaters transported on their mother's back were observed only during summer (December 2016 and November 2017). For T. tetradactyla, $89 \%(\mathrm{n}=8)$ of the records were of solitary individuals, while only one detection included a female with offspring, observed in November 2017.

Activity patterns. Both species showed a pattern of crepuscular and nocturnal activity with a peak of records around midnight (Fig. 5). M. tridactyla was recorded between $17 \mathrm{~h} 00$ and $09 \mathrm{~h} 00$, with the highest frequency of detection between $21 \mathrm{~h} 00$ and $01 \mathrm{~h} 00$ (58.8\%). Meanwhile, $T$. tetradactyla was recorded between $18 \mathrm{~h} 00$ and $02 \mathrm{~h} 00$, with the highest period of activity between $22 \mathrm{~h} 00$ and $01 \mathrm{~h} 00(55.4 \%)$. M. tridactyla was always detected between $11^{\circ} \mathrm{C}$ and $26^{\circ} \mathrm{C}$, while T. tetradactyla was always detected between $15^{\circ} \mathrm{C}$ and $23^{\circ} \mathrm{C}$.

Both species capture success was greater during spring time: $2 \%$ for $M$. tridactyla and $1.2 \%$ for $T$. tetradactyla (Tab. II), however, it should be noted that sampling was not evenly distributed for all seasons in all vegetation types due to floods caused by heavy rain. Sampling was conducted in all seasons of the year for FSF, in spring and summer for W-RF, and in autumn, winter and summer for MXF (Tab. I).

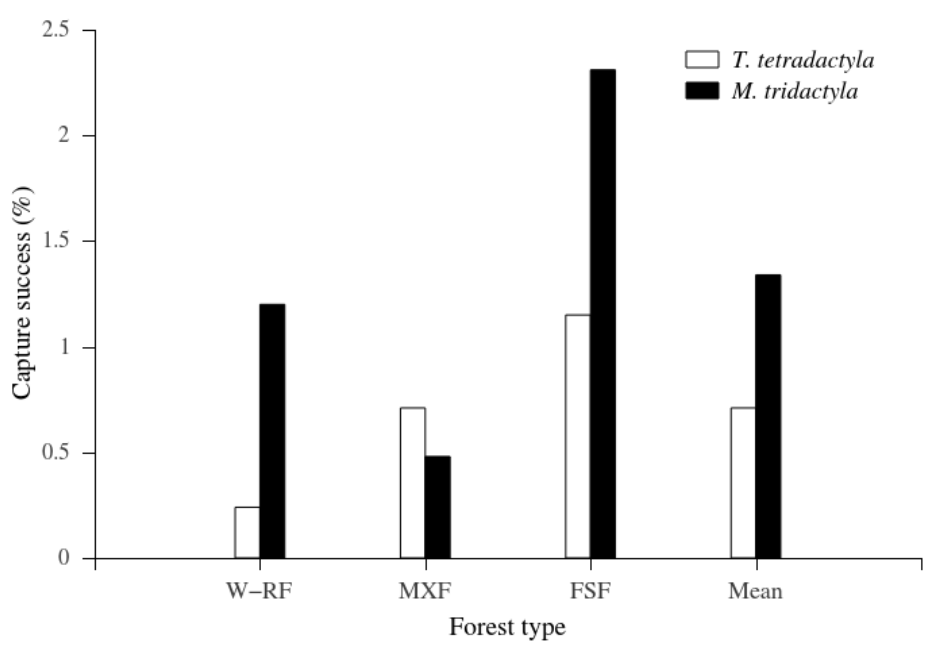

Fig. 4. Capture success (\%) of lesser anteater (Tamandua tetradactyla Linnaeus, 1758) and giant anteater (Myrmecophaga tridactyla Linnaeus, 1758) in the Humid Chaco Ecoregion in Paraguay using trap-cameras from November 2016 to March 2018 by forest types: W-RF, Riparian forests associated to wetlands; MXF, Mesoxerophytic semi-deciduous forests dominated by Schinopsis balansae; FSF, Floodable sub-humid forest islets. 


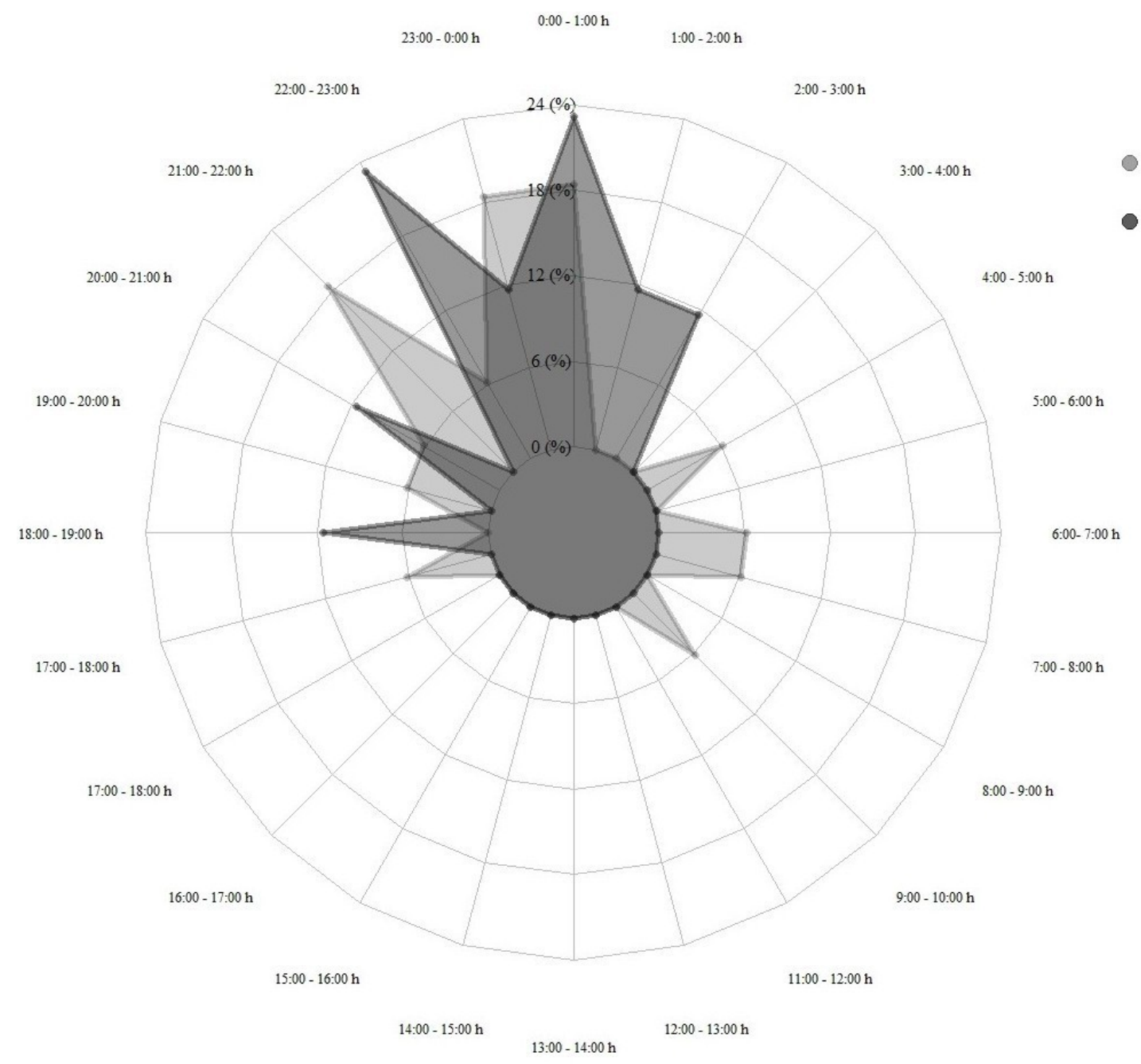

Fig. 5. Records (\%) by hour of the day of giant anteater (Myrmecophaga tridactyla Linnaeus, 1758) and lesser anteater (Tamandua tetradactyla Linnaeus, 1758 ) in the Humid Chaco Ecoregion in Paraguay using trap-cameras from November 2016 to March 2018.

\section{DISCUSSION}

Our results showed a preference of anteaters for the Floodable sub-humid forest islets (FSF), however, both species also appeared in other forest types. At a continental scale, giant anteaters are more frequently recorded in dry forests than in moist forests (Quiroga et al., 2016). Lesser anteaters are climbers and inhabit mainly forested environments and giant anteaters live in forested areas and in open areas, where they are more abundant due to their limited ability to climb (RoDRIGUES et al., 2008). However, a study carried out in the central region of the Pantanal (Brazil) reported the highest densities of M. tridactyla and $T$. tetradactyla in forest landscapes compared to open grasslands and scrubs, where they also were detected (DesBIEz \& MEDRI, 2010).

Our sampling site covered 500 ha in three forest types, grasslands and shrublands were not considered for this study. Studied forests islets are immersed in flood-prone savannas, however, camera-traps were only placed inside arboreal vegetation. Anteaters generally use a mosaic of habitats (e.g., forest islets for shelter and rest and savannas for foraging and daytime rest) (DESBIEZ \& MEDRI, 2010; QuIROGA et al., 2016), therefore, we recommend further research that also includes other plant formations. Size and shape of forest islets were not considered in this study because of their variability, while FSFs and the MXFs are larger and develop naturally in circular, oval or irregular shapes in slightly elevated areas of the floodplain; W-RFs are sinuous formations extending along wetlands and rivers.

Both species were usually detected alone, but occasionally females were observed carrying pups on their back, as reported by Desbiez \& Medri (2010), Figel et al. (2015) and Passos et al. (2016). Anteaters are usually nocturnal, although they occasionally engage in diurnal activity (RODRIGUES et al., 2008). According to our results, both species showed a pattern of crepuscular and nocturnal activity with a peak of records around midnight. Giant and lesser anteaters display both nocturnal and diurnal activity as part of a thermoregulatory behavior to avoid exposure during 
the hottest or coldest hours of the day (DesBiez \& MEDRI, 2010). Giant anteaters spend more hours active and are more nocturnal during summer, and wild-reared individuals are more nocturnal than captive-reared ones (Di Blanco et al., 2016). In some regions and during some periods, they display much more diurnal than nocturnal activity (RoDRIGUES et al., 2008). Activity patterns can be especially distinct in the southernmost limit of their geographic distribution which is characterized by marked thermal seasonality (Di BLANCO et al., 2016) as in the Humid Chaco.

Important limitations of this study are the small sampling size and limited number of camera-traps and the lack of systematic sampling during the four seasons of the year in the three analyzed forest types and in other plant formations of the study area, however, there are few published studies regarding anteaters in Paraguay and errors and contradictions persist in literature (SMITH, 2007, 2012; SMITH \& Rios, 2018). This research provides preliminary data on the species in the Humid Chaco, which is a key step for the design of conservation strategies for M. tridactyla and T. tetradactyla and as basis for further studies.

In addition to cattle and anteaters, camera-traps also recorded 43 species of wild animals of which three are threatened or near threatened: bare-faced curassow (Crax fasciolata), greater rhea (Rhea americana) and neotropical otter (Lontra longicaudis). Results suggest that cattle ranching activities developed in low-altered ecosystems, where low densities of cattle are maintained on native pastures (savannas) and the different types of forests are conserved, allow, so far, coexistence with anteaters and other wild animals.

Anteater populations are threatened by highway road kills and fire, which is the most common cause of $M$. tridactyla death in Brazil (SilveIra et al., 1999; FonseCA \& RYLANDS, 2004). Fire is an ecological component in the design of the vegetation of the Humid Chaco due to the high productivity of the herbaceous stratum and an insufficient level of herbivory to assimilate all the production of herbaceous biomass (GINZBURG \& ADAMOLI, 2006). In savannas, the presence of cattle along with the conservation of the forest islets could be a key combination for anteater conservation, highlighting the importance of conserving wetlands and their associated riparian forests in the region as natural refuges for wild animal species.

Acknowledgements. IDEA WILD for providing the cameratraps used in this research. Enoch Rinks, Rafaela Guanes and Domingo Laino for facilitating camera-traps transportation from USA to Paraguay. Lía Romero, Marcela Ferreira, Paloma Moreno, Rossana Macedo, Elianne Ferreira and Aldo Florentín for collaboration in placement of the cameras and data collection. We dedicate this work to the memory of Dr. Richard Alan White.

\section{REFERENCES}

Alzate-Gaviria, M.; González-Maya, J. F. \& Botero-Botero, A. 2016. Distribución geográfica y estado de conocimiento de las especies del género Tamandua (Xenarthra: Myrmecophagidae) en Colombia. Edentata 17:8-16.
APM - Asociación Paraguaya de Mastozoología \& SEAM - Secretaría del Ambiente. 2017. Libro Rojo de Mamíferos del Paraguay: especies amenazadas de extinción. Asunción, CREATIO. 137p.

Chiarello, A. G.; Costa, L. P.; Leite, Y. L. R.; Passamani, M.; Siciliano, S. \& ZorTÉA, M. 2007. Os mamíferos ameaçados de extinção no Estado do Espírito Santo. In: Passamani, M. \& Mendes, S. L. eds. Espécies da fauna ameaçadas de extinção no Estado do Espírito Santo. Vitória, Instituto de Pesquisas da Mata Atlântica, p. 29-45.

Collevatti, R.; Leite, K.; de Miranda, G. \& Rodrigues, F. 2007. Evidence of high inbreeding in a population of the endangered giant anteater, Myrmecophaga tridactyla (Myrmecophagidae), from Emas National Park, Brazil. Genetics and Molecular Biology 30(1):112-120.

De La Sancha, N. U.; López-González, C.; D’Elía, G.; Myers, P.; Valdez, L. \& Ortiz, M. L. 2017. An annotated checklist of the mammals of Paraguay. Therya 8:241-260.

De Matos, D.; Miranda, F. \& Guimarães, F. 2019. New record of giant anteater Myrmecophaga tridactyla (Pilosa, Myrmecophagidae) in Northeast Brazil. Neotropical Biology and Conservation 14(1):129135.

Desbiez, A. L. J. \& Medri, I. M. 2010. Density and habitat use by giant anteaters (Myrmecophaga tridactyla) and southern tamanduas (Tamandua tetradactyla) in the Pantanal wetland, Brazil. Edentata 11(1):4-10.

Di Blanco, Y. E.; SpørRing, K. L. \& Di Bitetti, M. S. 2016. Daily activity pattern of reintroduced giant anteaters (Myrmecophaga tridactyla): effects of seasonality and experience. Mammalia 81(1):11-21.

DMH - Meteorology and Hydrology Direction. 2018. Weather station data base WMO 86181 (20 km East of Benjamin Aceval, Presidente Hayes Department). Civil Aeronautic National Direction (DINAC), Manuel Gondra Foundation, National Science and Technology Council (Paraguay). Available at $<\mathrm{http} / / \mathrm{www}$.meteorologia.gov.py/emas/ estaciones $>$. Accessed on 30 Apr 2018.

Fallabrino, A. \& Castiñeira, E. 2006. Situación de los Edentados en Uruguay. Edentata 7:1-3.

Figel, J. J.; Botero-Cañola, S.; SÁnchez-Londoño, J. D. \& QuínteroÁngel, A. 2015. Unexpected documentation and inter-Andean range expansion of a vulnerable large mammal (Mammalia, Pilosa, Myrmecophaga tridactyla) in Colombia. Mammalia 80(4):449-452.

FonseCA, G. \& RYLAnds, A. eds. 2004. Edentata. The Newsletter of the IUCN Edentate specialist group, Number 6. Washington, Conservation International. 78p.

Fonseca, G. A. B.; Herrmann, G.; Leite, Y. R. L.; Mittermeier, R. A.; Rylands, A. B. \& Patton, J. L. 1996. Lista anotada dos mamíferos do Brasil. Occasional Papers in Conservation Biology 4:1-38.

Ginzburg, R. \& Adamoli, J. 2006. Situación Ambiental en el Chaco Húmedo. In: Brown, A.; Martínez Ortiz, U.; Acerbi, M. \& CORCUERA, J. eds. La Situación Ambiental Argentina 2005. Buenos Aires, Fundación Vida Silvestre Argentina, p.103-113.

IUCN - INTERNATIONAL UNION FOR CONSERVATION OF NATURE. 2014a. Myrmecophaga tridactyla. The IUCN Red List of Threatened Species. Version 2019-1. Available at $<$ http://www.iucnredlist.org $>$. Accessed on 27 May 2019.

IUCN - INTERNATIONAL UNION FOR CONSERVATION OF NATURE. 2014b. Tamandua tetradactyla. The IUCN Red List of Threatened Species. Version 2019-1. Available at $<$ http://www.iucnredlist.org $>$. Accessed on 27 May 2019.

Laino, L. D.; Musalem, K. \& Laino, R. 2017. Perspectivas para un desarrollo sustentable: un estudio de caso de producción ganadera en la región del Chaco paraguayo. Población y Desarrollo 23(45):95-106.

Mamalis, L.; Sousa da Silva, S.; Bezerra Valerio, A.; Norris, D. \& MichalsKi, F. 2018. Stepping stones facilitate river crossings by Myrmecophaga tridactyla in the north-eastern Brazilian Amazon. Edentata 19:30-34.

Maturo, H.; OAKLey, L. \& Prado, D. 2005. Vegetación y posición fitogeográfica de la Reserva El Bagual. In: Di Giacomo, A. G. \& Krapovickas, S. F. eds. Temas de Naturaleza y Conservacion. Buenos Aires, Monografía de Aves Argentinas, p. 59-73.

Mereles, F. 2005. Una aproximación al conocimiento de las formaciones vegetales del Chaco Boreal, Paraguay. Rojasiana 6(2):5-48. 
Mereles, F.; Cartes, J. L.; Clay, R. P.; Cacciali, P.; Paradeda, C.; Rodas, O. \& YANOSKY, A. 2013. Análisis cualitativo para la definición de las ecorregiones de Paraguay Occidental. Paraquaria Natural 1(2):12-20.

Miranda, F.; Bertassoni, A. \& AbBa, A. M. 2014a. Myrmecophaga tridactyla. The IUCN Red List of Threatened Species 2014. Available at $<\mathrm{http} / / / \mathrm{dx}$.doi.org/10.2305/IUCN.UK.2014-1.RLTS. T14224A47441961.en>. Accessed on 26 April 2018.

Miranda, F.; Chiarello, A.; Rohe, F.; Gons Braga, F.; de Miranda, G.; Braga, G.; Ferrari, K.; de Andrade, M.; Vaz, S. \& da Silva, S. 2018. Myrmecophaga tridactyla Linnaeus, 1758. In: Instituto Chico Mendes de Conservação da Biodiversidade. org. Livro Vermelho da Fauna Brasileira Ameaçada de Extinção: Volume II - Mamíferos. Brasília, ICMBio, p. 40-47.

Miranda, F.; Fallabrino, A.; Arteaga, M.; Tirira, D. G.; Meritt, D. A. \& SUPERINA, M. 2014b. Tamandua tetradactyla. The IUCN Red List of Threatened Species 2014. Available at $<\mathrm{http}$ ://dx.doi.org/10.2305/ IUCN.UK.2014-1.RLTS.T21350A47442916.en>. Accessed on 26 April 2018.

Miretzki, M. \& Braga, F. G. 2014. Distribuição Histórica e Recente de Myrmecophaga tridactyla Linnaeus, 1758 (Pilosa, Myrmecophagidae) no Estado do Paraná, Brasil. Edentata 15:16-26.

Paglia, A. P.; Fonseca, G. A. B.; Rylands, A. B.: Hermann, G.; Aguiar, L.; Chiarello, A.; Leite, Y.; Costa, L.; Siciliano, S.; KierulfF, M.; Mendes, S.; Tavares, V.; Mittermeier, R. \& Patton, J. 2012. Annotated Checklist of Brazilian Mammals. 2ed. Occasional Papers in Conservation Biology, No.6. Arlington, Conservation International. $76 \mathrm{p}$.

Passos, F. C.; Mello, M. C. H.; Isasi-Catalá, E.; Mello, R. C.; Bernardi, I. P.; VARZINCZAK, L. H. \& Lima, C. S. 2016. The Vulnerable giant anteater Myrmecophaga tridactyla: new records from the Atlantic Forest highlands and an overview of its occurrence in protected areas in Brazil. Oryx 51(3):564-566.

Peña-Chocarro, M.; De Egea, J.; Vera, M.; Maturo, H. \& Knapp, S. 2006. Guía de árboles y arbustos del Chaco Húmedo. Asunción, Darwin Initiative. 291p.
Perez de Molas, F. L. 2016. Manual de Familias y Géneros de Árboles del Paraguay. San Lorenzo, Organización de las Naciones Unidas para la Alimentación y la Agricultura. 227p

Perez Jimeno, G. \& Llarin Amaya, L. 2009. Contribución al conocimiento de la distribución del oso hormiguero gigante (Myrmecophaga tridactyla) en Argentina. Edentata 8-10:8-12.

Quiroga, V. A.; Jay Noss, A.; Boaglio, G. I. \& Di Bitetti, M. S. 2016. Local and continental determinants of giant anteater (Myrmecophaga tridactyla) abundance: Biome, human and jaguar roles in population regulation. Mammalian Biology 81(3):274-280.

Rodrigues, F. H. G.; Medri, I. M.; De Miranda, G. H. B.; Camilo-Alves, C. \& Mourão, G. 2008. Anteater behavior and ecology. In: VIZCAíno, S. F. \& Loughry, W. J. eds. The Biology of the Xenarthra. Gainesville, University Press of Florida, p. 257-268.

Semper-Pascual, A.; Macchi, L.; Sabatini, F.; Decarre, J.; Baumann, M.; Blendinger, P.; Gómez-Valencia, B.; Mastrangelo, M. \& KUEMMERLE, T. 2018. Mapping extinction debt highlights conservation opportunities for birds and mammals in the South American Chaco. Journal of Applied Ecology 55(3):1-12.

Silveira, L.; Rodrigues, F. H. G.; de Almeida JÁcomo, A. T. \& Diniz FiLHO, J. A. F. 1999. Impact of wildfires on the megafauna of Emas National Park, central Brazil. Oryx 33(2):108-114.

Sмiтн, P. 2007. Southern Tamandua Tamandua tetradactyla (Linnaeus, 1758). Fauna Paraguay Handbook of the Mammals of Paraguay N'3. 15p.

SмIтH, P. 2012. The Xenarthra families Myrmecophagidae and Dasypodidade. Fauna Paraguay Handbook of the Mammals of Paraguay $\mathbf{N}^{\circ} 2 \mathrm{a}$. 35p.

Smith, P. \& Rios, S. D. 2018. Distribution and status of Paraguayan Xenarthra: towards a better understanding. Edentata 19:1-29.

Srbek-Araujo, A. C. \& Garcia Chiarello, A. 2005. Is camera-trapping an efficient method for surveying mammals in neotropical forests? A case study in south-eastern Brazil. Journal of Tropical Ecology 21:121-125. 